\title{
THE EFFECT OF AUDIOVISUAL MEDIA BASED EDUCATION ON CHANGES IN ADOLESCENT'S ATTITUDES RELATED TO CIGARETTE ADVERTISING
}

\author{
Rengga Dwija Prasetya, Fenny Etrawati*, Yeni, Widya Lionita \\ Faculty of Public Health Sriwijaya University, Jl. Palembang Prabumulih KM 32, \\ Indralaya District Ogan Ilir, South Sumatera 30662, Indonesia
}

\begin{abstract}
Smoking behavior among adolescents is increasing. This condition is partly influenced by the incessant advertisements for cigarettes that offer expectations that are the opposite of their impact. This study aims to determine the effect of audiovisual media-based education in the context of changing adolescent attitudes towards cigarette advertisements. The study design used was a Quasi Experiment with a Pretest-Posttest with Control Group. The research subjects were college adolescents (students) with a total of 25 people in the intervention group and 25 in the control group. Data were analyzed using dependent $t$ test and independent $t$ test. In the intervention group, there was a significant difference between attitudes towards cigarette advertisements before and after being given audiovisual media related to cigarette advertising in the experimental group $(p=0.010)$, on the other hand there was no change in attitude in the control group ( $p=$ 0.760). However, there was no significant difference between attitudes towards cigarette advertising in the experimental and control groups $(p=0.096)$. Therefore, education using audiovisual media is considered more effective in increasing changes in attitudes towards cigarette advertisements. The campus is expected to reinforce and socialize regulations related to KTR and further research can conduct media pre-testing
\end{abstract}

Keywords: audiovisual media, animation video, attitude toward cigarettes advertisement

\begin{abstract}
ABSTRAK
Perilaku merokok pada kalangan remaja semakin meningkat. Kondisi inisalah satunya dipengaruhi oleh gencarnya iklan rokok yang menawarkan ekspektasi yang berkebalikan dari dampaknya. Penelitian ini bertujuan untuk mengetahui pengaruh edukasi berbasis media audiovisual dalam rangka perubahan sikap remaja terhadap iklan rokok. Desain studi yang digunakan adalah Quasi Eksperiment dengan Pretest-Posttest with Control Group. Subjek penelitian adalah remaja perguruan tinggi (mahasiswa) dengan jumlah 25 orang kelompok intervensi dan 25 orang kelompok kontrol. Data dianalisis menggunakan dependent $t$ test dan independent $t$ test. Pada kelompok intervensi, terdapat perbedaan secara signifikan antara sikap terhadap iklan rokok sebelum dan sesudah diberikan media audiovisual terkait iklan rokok pada kelompok eksperimen $(\mathrm{p}=0,010)$, sebaliknya tidak ada perubahan sikap pada kelompok kontrol $(\mathrm{p}=0,760)$. Namun tidak ada perbedaan yang signifikan antara sikap terhadap iklan rokok pada kelompok eksperimen dan kontrol $(\mathrm{p}=0,132)$. Oleh karena itu, edukasi menggunakan media audiovisual dinilai lebih efektif dalam meningkatkan perubahan sikap terhadap iklan rokok. Pihak kampus diharapkan untuk mempertegas dan mensosialisasikan peraturan terkait KTR dan penelitian selanjutnya dapat melakukan pre-testing media.
\end{abstract}

Keywords: media audiovisual, video animasi, sikap terhadap iklan rokok

Correspondece Address: Fenny Etrawati, Faculty of Public Health Sriwijaya University, , Jl.Palembang Prabumulih KM 32, Indralaya District Ogan Ilir, South Sumatera 30662, Indonesia, E-mail: fennyetrawati.unsri@gmail.com 


\section{Introduction}

Smoking behavior still becomes a health problem in the world. More than 1.1 billion people are smoking and 57\% are in the region of Asia and Australia, 14\% in Eastern Europe and the Soviet Union, 12\% in America, 9\% in Western Europe and 8\% in the Middle East and Africa. ${ }^{1}$ A total of $60 \%$ of the world's smokers at the period of 2010-2012 in 3 countries of Asia such as China, India, and Indonesia. ${ }^{2}$ Indonesia has 53,717 active smokers and is a country with the most third most active proper exercise in the world, after China and India. ${ }^{3}$ The percentage of teenage smokers in Indonesia that is analysed based on the ages is found at the range between 20-24 years is $27.2 \%$. South Sumatera is a province with the proportion of the second most smokers after Bengkulu for the Region of Sumatera with the percentage of smokers in the ages about 20-24 of $24.9 \%$ of the total number of teenage smokers in South Sumatera. ${ }^{4}$

The highest proportion of active smokers in South Sumatra is occupied by South OKU district is about $36.2 \%$ while the Palembang city is only $22.6 \%$. The proportion of active smokers in Palembang City is not the highest proportion of active smokers in South Sumatera, but Palembang City has the largest population which reach about 1,651,857 people so the estimation of smokers are many more than other districts. ${ }^{5}$ There are at least 373,319 smokers in Palembang City and 1067 of the people are teenagers. ${ }^{6}$

Cigarettes advertising were one of the factors affecting attitudes for smoking. ${ }^{7}$ Ads are also a comprehensive strategy that is done by the cigarette industry in influencing teenage attitude. The cigarette industry targets the teenagers because they need new smokers who will replace the half of the heal of the user, so the cigarette industry can be continued. ${ }^{8}$ The result of the surveys which is conducted at 16 regencies / Cities in South Sumatra showed that most of the people are exposed by cigarette advertising via TV (83.1\%), banner (77.50\%), billboard (69.90\%), poster $(67.80 \%)$, and public wall $(56.50 \%)^{9}$. The government has made some attempted preventive of the behavior of the smoking including through the campaign of the healthy community of the community of life (GERMAS) and the unit stops smoking (UBM) but its success is not significant. Based on Tobacco Atlas's view, Indonesia is successful to make progress in tobacco control in recent years. However, the number of people who died and ill-pain and the disadvantage of society due to the use of tobacco continues to Increase. At least 3.9\% of children aged (10-14 years) and $68.7 \%$ of teenagers and adults $(>15$ years) sucked cigarettes every day and mortality rates triggered by smoking behavior achieved $28.39 \%{ }^{3}$

The influence of cigarettes in the teenage group becomes the problem to be solved, one of the efforts itself is by educational efforts to change teenage attitudes related to cigarette advertising. In the digital era of allowing innovation in the development of messages for pads of precautions due 
to cigarettes such as cigarette through media design audiovisions such as short video. ${ }^{10}$ Based on the results of previous research, the audio visual media is considered able to create positive attitude changes to prevent smoking behavior in adolescents. ${ }^{11}$ Attitudes may not be formed before getting information (educational), seeing and experiencing itself a state. ${ }^{12}$ This is in line with the concept of behavioral changes where levels of literacy (knowledge) affect the way a person in addressing a thing and attitudes will be a sign of change in behavior. In general, the way of educational delivery using conventional methods (lectures). Therefore, the researcher conducted intervention to the behavior issues among teenagers through educational activities using audiovisual media (animation videos) compared to the lecture method containing information about the controversies of cigarettes in cigarette advertising. The goal of this education is to encourage the change of adolescence to advertising to cigarette advertising towards a more positive in preventing behavior of smoking. This study aims to determine the effect of audiovisual media-based education in the context of changing adolescent attitudes towards cigarette advertisements.

\section{Method}

This research used quantitative research with Quasi Experiment design which has PreterestPosttest with Control Group research design. The population of this study was the adolescents in one of the universities in Palembang with the criteria ever exposed to cigarette advertising and ages ranging 15-24 years. The researcher took 2 courses that will then be used as a group of interventions and control groups, the method of determining using the method of doll the (coat and the back of the control group as the control group). Sampling of research is chosen by Purposive Sampling method based on the response criterion is an active student in the selected study program. Based on the minimum sample calculation using tare he average pairing (paired) variation formula, the subjects of this research 50 samples which are devided into 2 groups including 25 samples of experimental group and 25 samples of control group. The researcher conducted interventions at 2 groups separately in a closed space so that minimized his bias, providing informed consent and data collection through pretest before starting intervention. Furthermore, the intervention group was educated through 10-minute animation videos designed by the researcher and already tested.

The Animation video used in the study contains various information related to the cigarette ads with accompanied by the explanation of the hidden meaning of the ads and the emphasis to encourage the change of adolescence to not be troubled in cigarettes. Meanwhile, the control group was educated by applying the lecture method using Power Point containing the same content as animated video. After the intervention activity is completed, the final data collection is done through Posttest. 
The variables measured in this study are the attitude of cigarette advertising in adolescents. Data collection is done with self assessment using questionnaires that have been tested its validity and reliability before and after the intervention. Furthermore, data is analyzed univariate and bivariate using dependent test $t$ test and independent test $t$ test. This study has escaped the study of Ethics with No. 316 / un9.1.10 / KKE / 2020

\section{Results}

The variables that measured in this study were adolescent attitudes related to cigarette advertisements by used the analysis dependent $t$ test and independent $t$ test. The results of data analysis are presented in a univariate data analysis table that describes the items of the questions in the study. In addition, the researcher also puts a table of bivariate analysis results that illustrates the changes in respondents' attitudes towards cigarette advertisements before and after the implementation of the intervention in groups that were educated using animated videos and educated using conventional methods (lectures).

The following is an overview of the results of the research data analysis consisting of the characteristics of the respondent, the score of attitudes towards cigarette advertising before and after the intervention in the intervention group and the control group.

Table 1. Distribution of Respondents Characteristics

\begin{tabular}{|c|c|c|c|c|}
\hline \multirow{3}{*}{ Variable } & \multicolumn{4}{|c|}{ Group } \\
\hline & \multicolumn{2}{|c|}{ Eksperiment } & \multicolumn{2}{|c|}{ Control } \\
\hline & $\mathrm{n}$ & $\%$ & $\mathrm{n}$ & $\%$ \\
\hline \multicolumn{5}{|l|}{ Ages } \\
\hline 17 Years old & 1 & 4 & - & - \\
\hline 18 Years old & 12 & 48 & - & - \\
\hline 19 Yearsold & 11 & 44 & 4 & 16 \\
\hline 20 Yearsold & 1 & 4 & 15 & 60 \\
\hline 21 Yearsold & - & - & 4 & 16 \\
\hline 22 Yearsold & - & - & 1 & 4 \\
\hline 23 Yearsold & - & - & 1 & 4 \\
\hline \multicolumn{5}{|l|}{ Gender } \\
\hline Male & 3 & 12 & 11 & 44 \\
\hline Female & 22 & 88 & 14 & 56 \\
\hline
\end{tabular}

Based on table, it shows that the age of the respondents in this study was quite varied, but they were included in the category of adolescents. In the experimental group, the youngest respondent was 17 years old while the oldest was 20 years old with the most respondents being 18 years old. Meanwhile, in the control group the youngest respondents were 19 years old, while the oldest were 23 years old with the most respondents being 20 years old. The table also provides information that in the two groups (intervention and control) respondents were dominated by 
female respondents, but the number of male respondents in the control group was more than the intervention group.

Table 2. Distribution of Attitudes at Pretest and Posttest in the Experimental Group

\begin{tabular}{|c|c|c|c|c|c|c|c|c|c|c|c|}
\hline \multirow[t]{2}{*}{ No } & \multirow[t]{2}{*}{ Questions } & \multicolumn{5}{|c|}{ Pretest } & \multicolumn{5}{|c|}{ Posttest } \\
\hline & & SS & $\mathbf{S}$ & $\mathbf{R}$ & TS & STS & SS & $\mathbf{S}$ & $\mathbf{R}$ & TS & STS \\
\hline & $\begin{array}{l}\text { I am terrified of the } \\
\text { warning that says } \\
\text { "smoking kills you" on } \\
\text { the cigarette package. }\end{array}$ & $\begin{array}{c}15 \\
60 \%\end{array}$ & $\begin{array}{c}6 \\
24 \%\end{array}$ & $\begin{array}{c}1 \\
4 \%\end{array}$ & $\begin{array}{c}1 \\
4 \%\end{array}$ & $\begin{array}{c}2 \\
8 \%\end{array}$ & $\begin{array}{c}15 \\
60 \%\end{array}$ & $\begin{array}{c}8 \\
32 \%\end{array}$ & $\begin{array}{c}1 \\
4 \%\end{array}$ & $\begin{array}{c}1 \\
4 \%\end{array}$ & 0 \\
\hline 2. & $\begin{array}{l}\text { I am not afraid to see } \\
\text { pictures of the effects } \\
\text { of disease caused by } \\
\text { smoking on cigarette } \\
\text { packs. }\end{array}$ & $\begin{array}{c}1 \\
4 \%\end{array}$ & $\begin{array}{c}1 \\
4 \%\end{array}$ & 0 & $\begin{array}{c}11 \\
44 \%\end{array}$ & $\begin{array}{c}12 \\
48 \%\end{array}$ & $\begin{array}{c}1 \\
4 \%\end{array}$ & $\begin{array}{c}1 \\
4 \%\end{array}$ & 0 & $\begin{array}{c}13 \\
52 \%\end{array}$ & $\begin{array}{c}10 \\
40 \%\end{array}$ \\
\hline 3. & $\begin{array}{l}\text { Teens who smoke look } \\
\text { cooler and macho } \\
\text { when compared to } \\
\text { teens who don't smoke. }\end{array}$ & 0 & $\begin{array}{c}2 \\
8 \%\end{array}$ & $\begin{array}{c}1 \\
4 \%\end{array}$ & $\begin{array}{c}5 \\
20 \%\end{array}$ & $\begin{array}{c}17 \\
68 \%\end{array}$ & $\begin{array}{c}1 \\
4 \%\end{array}$ & 0 & $\begin{array}{c}1 \\
4 \%\end{array}$ & $\begin{array}{c}10 \\
40 \%\end{array}$ & $\begin{array}{c}13 \\
52 \%\end{array}$ \\
\hline 4. & $\begin{array}{l}\text { Based on the } \\
\text { advertisement, it does } \\
\text { not appear that } \\
\text { smoking is dangerous. }\end{array}$ & $\begin{array}{c}4 \\
16 \%\end{array}$ & $\begin{array}{c}3 \\
12 \%\end{array}$ & $\begin{array}{c}4 \\
16 \%\end{array}$ & $\begin{array}{c}9 \\
36 \%\end{array}$ & $\begin{array}{c}5 \\
20 \%\end{array}$ & $\begin{array}{c}5 \\
20 \%\end{array}$ & $\begin{array}{c}5 \\
20 \%\end{array}$ & $\begin{array}{c}1 \\
4 \%\end{array}$ & $\begin{array}{c}9 \\
36 \%\end{array}$ & $\begin{array}{c}5 \\
20 \%\end{array}$ \\
\hline 5. & $\begin{array}{l}\text { I agree that cigarette } \\
\text { advertisements are } \\
\text { only broadcast at } 21.30 \\
-05.00 \text { on television. }\end{array}$ & $\begin{array}{c}2 \\
8 \%\end{array}$ & $\begin{array}{l}10 \\
40 \%\end{array}$ & $\begin{array}{c}1 \\
4 \%\end{array}$ & $\begin{array}{c}9 \\
36 \%\end{array}$ & $\begin{array}{c}3 \\
12 \%\end{array}$ & $\begin{array}{c}2 \\
8 \%\end{array}$ & $\begin{array}{c}10 \\
40 \%\end{array}$ & $\begin{array}{c}5 \\
20 \%\end{array}$ & $\begin{array}{c}5 \\
20 \%\end{array}$ & $\begin{array}{c}3 \\
12 \%\end{array}$ \\
\hline 6. & $\begin{array}{l}\text { I will accept it if I am } \\
\text { offered a scholarship } \\
\text { by a tobacco company }\end{array}$ & $\begin{array}{c}3 \\
12 \%\end{array}$ & $\begin{array}{c}4 \\
16 \%\end{array}$ & $\begin{array}{c}7 \\
28 \%\end{array}$ & $\begin{array}{c}5 \\
20 \%\end{array}$ & $\begin{array}{c}6 \\
24 \%\end{array}$ & $\begin{array}{c}1 \\
4 \%\end{array}$ & $\begin{array}{c}1 \\
4 \%\end{array}$ & $\begin{array}{c}5 \\
20 \%\end{array}$ & $\begin{array}{c}8 \\
32 \%\end{array}$ & $\begin{array}{c}10 \\
40 \%\end{array}$ \\
\hline 7. & $\begin{array}{l}\text { I will watch the } \\
\text { cigarette advertisement } \\
\text { on television until the } \\
\text { end because the } \\
\text { content is interesting } \\
\text { and creative }\end{array}$ & $\begin{array}{c}3 \\
12 \%\end{array}$ & $\begin{array}{c}5 \\
20 \%\end{array}$ & $\begin{array}{c}8 \\
32 \%\end{array}$ & $\begin{array}{c}5 \\
20 \%\end{array}$ & $\begin{array}{c}4 \\
16 \%\end{array}$ & $\begin{array}{c}2 \\
8 \%\end{array}$ & $\begin{array}{c}5 \\
20 \%\end{array}$ & $\begin{array}{c}4 \\
16 \%\end{array}$ & $\begin{array}{c}9 \\
36 \%\end{array}$ & $\begin{array}{c}5 \\
20 \%\end{array}$ \\
\hline 8. & $\begin{array}{l}\text { I allow small children } \\
\text { or my younger siblings } \\
\text { to watch cigarette } \\
\text { commercials that } \\
\text { appear on television }\end{array}$ & $\begin{array}{c}4 \\
16 \%\end{array}$ & $\begin{array}{c}6 \\
24 \%\end{array}$ & $\begin{array}{c}3 \\
12 \%\end{array}$ & $\begin{array}{c}8 \\
32 \%\end{array}$ & $\begin{array}{c}4 \\
16 \%\end{array}$ & $\begin{array}{c}1 \\
4 \%\end{array}$ & $\begin{array}{c}3 \\
12 \%\end{array}$ & $\begin{array}{c}2 \\
8 \%\end{array}$ & $\begin{array}{c}11 \\
44 \%\end{array}$ & $\begin{array}{c}8 \\
32 \%\end{array}$ \\
\hline 9. & $\begin{array}{l}\text { My friendship gets } \\
\text { better by sharing } \\
\text { cigarettes when I get } \\
\text { together. }\end{array}$ & 0 & 0 & 0 & $\begin{array}{c}10 \\
40 \%\end{array}$ & $\begin{array}{c}15 \\
60 \%\end{array}$ & $\begin{array}{c}1 \\
4 \%\end{array}$ & 0 & 0 & $\begin{array}{c}11 \\
44 \%\end{array}$ & $\begin{array}{c}13 \\
52 \%\end{array}$ \\
\hline 10. & $\begin{array}{l}\text { Smoking is an } \\
\text { Indonesian culture that } \\
\text { must be preserved }\end{array}$ & 0 & 0 & 0 & $\begin{array}{c}4 \\
16 \%\end{array}$ & $\begin{array}{c}21 \\
84 \%\end{array}$ & $\begin{array}{c}1 \\
4 \%\end{array}$ & 0 & 0 & $\begin{array}{c}5 \\
20 \%\end{array}$ & $\begin{array}{c}19 \\
76 \%\end{array}$ \\
\hline
\end{tabular}

Based on table 2 it can be seen that before the intervention, most of the respondents said they were afraid of the warning "smoking kills you" and pictures of smoking-related diseases printed on cigarette packs, then after the intervention the percentage increased. In addition, there was a positive change in the perception of youth towards cigarette sponsors that they are prefers to reject cigarette scholarships. On the other hand, there was a decrease in resistance to the claim that smoking makes friendship better and this was a part of Indonesian culture. 
Table 3. Distribution of Attitudes at Pretest and Posttest in the Control Group

\begin{tabular}{|c|c|c|c|c|c|c|c|c|c|c|c|}
\hline \multirow[t]{2}{*}{ No } & \multirow[t]{2}{*}{ Questions } & \multicolumn{5}{|c|}{ Pretest } & \multicolumn{5}{|c|}{ Posttest } \\
\hline & & SS & $\mathbf{S}$ & $\mathbf{R R}$ & TS & STS & SS & $\mathbf{S}$ & $\mathbf{R R}$ & TS & STS \\
\hline 1. & $\begin{array}{l}\text { I am terrified of the } \\
\text { warning that says } \\
\text { "smoking kills you" } \\
\text { on the cigarette } \\
\text { package. }\end{array}$ & $\begin{array}{c}14 \\
56 \%\end{array}$ & $\begin{array}{c}6 \\
24 \%\end{array}$ & $\begin{array}{c}1 \\
4 \%\end{array}$ & $\begin{array}{c}2 \\
8 \%\end{array}$ & $\begin{array}{c}2 \\
8 \%\end{array}$ & $\begin{array}{c}11 \\
44 \%\end{array}$ & $\begin{array}{c}9 \\
36 \%\end{array}$ & $\begin{array}{c}2 \\
8 \%\end{array}$ & $\begin{array}{c}2 \\
8 \%\end{array}$ & $\begin{array}{c}1 \\
4 \%\end{array}$ \\
\hline 2. & $\begin{array}{l}\text { I am not afraid to see } \\
\text { pictures of the effects } \\
\text { of disease caused by } \\
\text { smoking on cigarette } \\
\text { packs. }\end{array}$ & $\begin{array}{c}4 \\
16 \%\end{array}$ & $\begin{array}{c}3 \\
12 \%\end{array}$ & $\begin{array}{c}1 \\
4 \%\end{array}$ & $\begin{array}{c}8 \\
32 \%\end{array}$ & $\begin{array}{c}9 \\
36 \%\end{array}$ & 0 & $\begin{array}{c}6 \\
24 \%\end{array}$ & $\begin{array}{c}3 \\
12 \%\end{array}$ & $\begin{array}{c}10 \\
40 \%\end{array}$ & $\begin{array}{c}6 \\
24 \%\end{array}$ \\
\hline 3. & $\begin{array}{l}\text { Teens who smoke } \\
\text { look cooler and } \\
\text { macho when } \\
\text { compared to teens } \\
\text { who don't smoke. }\end{array}$ & 0 & 0 & $\begin{array}{c}2 \\
8 \%\end{array}$ & $\begin{array}{c}9 \\
36 \%\end{array}$ & $\begin{array}{l}14 \\
56 \%\end{array}$ & 0 & 0 & $\begin{array}{c}4 \\
16 \%\end{array}$ & $\begin{array}{c}13 \\
52 \%\end{array}$ & $\begin{array}{c}8 \\
32 \%\end{array}$ \\
\hline 4. & $\begin{array}{l}\text { Based on the } \\
\text { advertisement, it does } \\
\text { not appear that } \\
\text { smoking is dangerous. }\end{array}$ & $\begin{array}{c}7 \\
28 \%\end{array}$ & $\begin{array}{c}3 \\
12 \%\end{array}$ & $\begin{array}{c}1 \\
4 \%\end{array}$ & $\begin{array}{c}6 \\
24 \%\end{array}$ & $\begin{array}{c}8 \\
32 \%\end{array}$ & $\begin{array}{c}9 \\
36 \%\end{array}$ & $\begin{array}{c}5 \\
20 \%\end{array}$ & $\begin{array}{c}2 \\
8 \%\end{array}$ & $\begin{array}{c}4 \\
16 \%\end{array}$ & $\begin{array}{c}5 \\
20 \%\end{array}$ \\
\hline 5. & $\begin{array}{l}\text { I agree that cigarette } \\
\text { advertisements are } \\
\text { only broadcast at } \\
21.30-05.00 \text { on } \\
\text { television. }\end{array}$ & $\begin{array}{c}7 \\
28 \%\end{array}$ & $\begin{array}{c}5 \\
20 \%\end{array}$ & $\begin{array}{c}2 \\
8 \%\end{array}$ & $\begin{array}{c}7 \\
28 \%\end{array}$ & $\begin{array}{c}4 \\
16 \%\end{array}$ & $\begin{array}{c}7 \\
28 \%\end{array}$ & $\begin{array}{c}12 \\
48 \%\end{array}$ & $\begin{array}{c}2 \\
8 \%\end{array}$ & $\begin{array}{c}3 \\
12 \%\end{array}$ & $\begin{array}{c}1 \\
4 \%\end{array}$ \\
\hline 6. & $\begin{array}{l}\text { I will accept it if I am } \\
\text { offered a scholarship } \\
\text { by a tobacco } \\
\text { company. }\end{array}$ & $\begin{array}{c}4 \\
16 \%\end{array}$ & $\begin{array}{c}4 \\
16 \%\end{array}$ & $\begin{array}{c}3 \\
12 \%\end{array}$ & $\begin{array}{c}6 \\
24 \%\end{array}$ & $\begin{array}{c}8 \\
32 \%\end{array}$ & $\begin{array}{c}2 \\
8 \%\end{array}$ & $\begin{array}{c}8 \\
32 \%\end{array}$ & $\begin{array}{c}5 \\
20 \%\end{array}$ & $\begin{array}{c}4 \\
16 \%\end{array}$ & $\begin{array}{c}6 \\
24 \%\end{array}$ \\
\hline 7. & $\begin{array}{l}\text { I will watch the } \\
\text { cigarette } \\
\text { advertisement on } \\
\text { television until the } \\
\text { end because the } \\
\text { content is interesting } \\
\text { and creative. }\end{array}$ & $\begin{array}{c}5 \\
20 \%\end{array}$ & $\begin{array}{c}6 \\
24 \\
\%\end{array}$ & $\begin{array}{c}4 \\
16 \%\end{array}$ & $\begin{array}{c}6 \\
24 \%\end{array}$ & $\begin{array}{c}4 \\
16 \%\end{array}$ & $\begin{array}{c}5 \\
20 \%\end{array}$ & $\begin{array}{c}7 \\
28 \%\end{array}$ & $\begin{array}{c}4 \\
16 \%\end{array}$ & $\begin{array}{c}4 \\
16 \%\end{array}$ & $\begin{array}{c}5 \\
20 \%\end{array}$ \\
\hline 8. & $\begin{array}{l}\text { I allow small children } \\
\text { or my younger } \\
\text { siblings to watch } \\
\text { cigarette commercials } \\
\text { that appear on } \\
\text { television. }\end{array}$ & $\begin{array}{c}4 \\
16 \%\end{array}$ & $\begin{array}{c}3 \\
12 \%\end{array}$ & $\begin{array}{c}2 \\
8 \%\end{array}$ & $\begin{array}{c}7 \\
28 \%\end{array}$ & $\begin{array}{c}9 \\
36 \%\end{array}$ & $\begin{array}{c}2 \\
8 \%\end{array}$ & $\begin{array}{c}7 \\
28 \%\end{array}$ & $\begin{array}{c}1 \\
4 \%\end{array}$ & $\begin{array}{c}7 \\
28 \%\end{array}$ & $\begin{array}{c}8 \\
32 \%\end{array}$ \\
\hline 9. & $\begin{array}{l}\text { My friendship gets } \\
\text { better by sharing } \\
\text { cigarettes when I get } \\
\text { together. }\end{array}$ & $\begin{array}{c}2 \\
8 \%\end{array}$ & $\begin{array}{c}2 \\
8 \%\end{array}$ & $\begin{array}{c}2 \\
8 \%\end{array}$ & $\begin{array}{c}9 \\
36 \%\end{array}$ & $\begin{array}{c}10 \\
40 \%\end{array}$ & $\begin{array}{c}1 \\
4 \%\end{array}$ & $\begin{array}{c}2 \\
8 \%\end{array}$ & $\begin{array}{c}5 \\
20 \%\end{array}$ & $\begin{array}{c}8 \\
32 \%\end{array}$ & $\begin{array}{c}9 \\
36 \%\end{array}$ \\
\hline 10. & $\begin{array}{l}\text { Smoking is an } \\
\text { Indonesian culture } \\
\text { that must be } \\
\text { preserved. }\end{array}$ & 0 & 0 & $\begin{array}{c}2 \\
8 \%\end{array}$ & $\begin{array}{c}7 \\
28 \%\end{array}$ & $\begin{array}{c}16 \\
64 \%\end{array}$ & $\begin{array}{c}1 \\
4 \%\end{array}$ & $\begin{array}{c}1 \\
4 \%\end{array}$ & $\begin{array}{c}3 \\
12 \%\end{array}$ & $\begin{array}{c}3 \\
12 \%\end{array}$ & $\begin{array}{c}17 \\
68 \%\end{array}$ \\
\hline
\end{tabular}

Table 3 shows that the results of the attitude assessment before the intervention showed that the majority of respondents claimed to be afraid of a written warning saying "smoking kills you" printed on the box. On the other hand, there is a decrease in the percentage of the assumption that cigarettes will make people better, perceptions of the timeliness of Indonesian tenderness of 
smoking students, and the assumption that smoking is part of Indonesian culture. The perception of the timeliness of the broadcast of cigarette advertisements, the tendency of Indonesian cigarette students, and the assumption that cigarettes are part of Indonesian culture.

The results of the data normality test showed that the data were normally distributed so that the bivariate test used was the dependent $t$ test and the independent $t$ test.

Table 4. Differences in the Effect of Interventions using Video Animation and the Lecture Method

\begin{tabular}{llccccc}
\hline Group & $\begin{array}{l}\text { Attitude of Cigarette } \\
\text { Advertising }\end{array}$ & Mean & SD & SE & \multirow{2}{*}{ Pvalue } & \multirow{2}{*}{$\mathrm{n}$} \\
\hline Intervention & Pretest & 36,92 & 4,94 & 0,98 & \multirow{2}{*}{0,010} & 25 \\
\hline (Animated video) & Posttest & 39,28 & 5,20 & 1,04 & & \multirow{2}{*}{25} \\
Control & Pretest & 36,52 & 6,32 & 1,26 & \multirow{2}{*}{0,760} & 25 \\
\hline
\end{tabular}

Table 4 shows that the average score of the respondent's attitude before getting intervention with audiovisual media (video animation) was 36.92, and it increased to 39.28 after the intervention was carried out. Based on the paired t-test results obtained p-value 0.010, which means that Audiovisual counseling (video animation) can have a significant effect on increasing respondents' attitudes regarding cigarette advertisements. In the control group, the average score for the attitude of the respondents before receiving the lecture method education was 36.52 , and increased to 36.84 after intervention. Based on the paired t-test results obtained $p$-value 0.760 , which means that Extension with the lecture method could not have a significant effect on increasing the respondent's attitude regarding cigarette advertising.

Table 5. Differences in Average Attitudes towards Cigarette Advertising in the Experiment and Control Group

\begin{tabular}{lllcc}
\hline Kelompok & SD & Mean & Mean different & P Value \\
\hline Audio Visual (Video Animasi) & 0,41 & 0,236 & 2,04 & \\
\cline { 1 - 3 } Ceramah & 0,51 & 0,032 & 0,132 \\
\hline
\end{tabular}

Table 5, shows that it can be seen that the average change in attitude scores in the experimental group which was given counseling with Audio Visual (Animated Videos) equal to 0.236 with a standard deviation (distribution of data in the sample) 0.41 , while the average change in the attitude score of respondents in the control group who was given counseling with the lecture method was 0.032 with a standard deviation of 0.51 . The statistical test results obtained $p$-value $0.132>0.05$, which means statistically, there is no difference in attitudes between respondents who received audio visual education (Video Animation) and respondents who received counseling using the lecture method. The mean difference between the experimental groups used audio-visual media (video animation) and the control group using the lecture method was 0.204 which means that the 
group using audio visual media (animated video) is considered more effective than lecture method in influencing attitudes regarding cigarette advertising.

\section{Discussions}

This study aims to measure the change in adolescent attitudes related to cigarette advertising with the age range of respondents between 18 and 25 years. Those age group was included in the late adolescent/early adult category. Based on its development, this group of adolescents is in the stages of stabilization of life stance. ${ }^{13}$ Someone who is a teenager is not really critical in dealing with smoking, they pay less attention to the health consequences of smoking, because they believe that they can quit smoking easily and anytime they want. ${ }^{14}$ So it must be balanced with knowledge and a good attitude towards cigarettes.

In general, smoking behavior is higher in males than females, due to the nature of male adolescents who are more likely to take risks, the presence of "peer pressure" group power, higher curiosity, and environmental influences. ${ }^{9}$ In addition, smoking is also very familiar with social activities and makes adolescents have a high sense of addiction to cigarettes, it makes more difficult to quit smoking. ${ }^{15}$

Adolescent smoking behavior is strongly influenced by cigarette advertisements. Cigarette advertisements broadcast in the mass media are very creative, and the majorities portray cigarettes with a cool, slang, confident, adventurous spirit, loyal friends and macho, resulting in consumptive behavior. ${ }^{16}$ In fact, sometimes the cigarette advertisements are allowed to be enjoyed by children. Cigarette advertisements in the mass media do not relatively portray cigarettes as dangerous. The image presented through advertisements leads to many social aspects, such as a cooler and more macho appearance, better friendships/associations, and camouflage that smoking is a culture that must be preserved. ${ }^{17}$ The stronger the adolescent's attitude to smoking, the more likely it is that adolescents will influence their closest friends to smoke. ${ }^{18}$

Cigarette advertisements can also be in the form of Coorporate Social Responsibility programs such as providing scholarships. Through this program, one of the largest cigarette companies in Indonesia has succeeded in changing the image of a cigarette company that is considered bad by the community, into a good image and even received an award for caring for education in $2010 .{ }^{19}$ This has proven to be a way of advertising in an indirect way to get sympathy from consumers.

Teenagers as cigarette consumers tend to ignore written or visual warnings about the dangers of smoking. This contradicts with the purpose of the warning which was to increase knowledge of the effects of smoking to reduce smoking behavior. ${ }^{20}$ Most of the teenagers will enjoy cigarette advertisements displayed on television. ${ }^{21}$ So it makes a harmless cigarette image. However, efforts to reduce smoking behavior are currently combined with written and visual messages and this 
method is considered successful enough to scare those who saw it, many countries have adopted this concept either. ${ }^{22}$

In order to reduce cigarette consumption among adolescents, researchers designed an educational method based on audiovisual media. The formation of understanding will stimulate changes in respondent attitudes and actions and so that adolescents can avoid the bad effects of smoking, especially health impacts. ${ }^{14,23}$ In addition, a change in attitude is also indicated through a change in perception in choosing to start, continue or stop behavior. ${ }^{24}$ The superiority of education using audio-visual media is proven to be able to increase the attractiveness of adolescents to understand the contents of the message and to be able to last a long time in the individual's memory, but its one-way communication is a weakness of this method. On the other hand, the lecture method has advantages related to the intensity of the interaction (two-way communication) even though power point media tends to only present writing and images with lower effectiveness than audiovisual media.

The audiovisual media-based educational design in this study proved to be more effective than the conventional method (lecture) in which there were no disturbances observed during the study when the two interventions took place. This is because the delivery of messages related to smoking through audiovisual media is more able to focus cognitively on repeating information so that it can influence a person's thoughts and behavior. ${ }^{25}$ The limitations of this study are the presence of variables confounding that may interfere with the results of the study, such as the level of literacy related to the impact of smoking and perceptions in the family/environment related to cigarette advertising.

\section{Conclusion}

Intervention using Audiovisual media (Video Animation) can have a significant effect on changes in adolescent attitudes related to cigarette advertising, while the intervention using the lecture method does not significantly change adolescent attitudes. The mean difference in attitude regarding cigarette advertising between the experimental group and the control group was 2,04. Attitude aspects in the intervention group that experienced positive changes after being educated using audio-visual media (animation) included fear of warning writing on cigarette packs, cigarette advertisements not depicting the negative side of cigarettes, rejection of cigarette advertisements, no need to listen to cigarette advertisements, the obligation to protect siblings. exposure to cigarette advertisements and the awareness that smoking is not part of Indonesian culture. Meanwhile, in the control group, aspects of attitude that experienced positive changes included fear of visualizing the impact of smoking, rejection of cigarette advertisements and the timeliness of serving cigarette advertisements. It can be concluded that education using audiovisual media is more effective than the lecture method because audiovisual media is able to stimulate individual understanding better 
and can be retained longer in memory. Therefore, it is necessary to expand similar interventions and or combine the two intervention methods namely audiovisual media and lectures to targerts group both at school and outside of school in order to reduce the incidence of new smokers. In addition, it requires commitment from all parties in implementing Smoking Free Areas and restricting youth access to cigarettes.

\section{Acknowledgement}

The researcher are grateful to The Research and Community Service Institute of Sriwijaya University for providing which has provided full funding for this research process. The researchers also said thanks you to the team of enumerartor and educational institutions where activities have been implemented that made the intervention program successful.

\section{Funding}

This study was fully funded by DIPA Budget Sriwijaya University for Public Service consideration year 2019 No. SP DIPA-042.01.2.400953/2019 on 5th of Desember 2018 in accordance with the reference from The Rector of Science Technology and Art Research Number: 0016/UN9/SK.LP2M.PT/2019 on 21st of Juni 2019.

\section{Conflict of Interest}

No conflict of interest

\section{Reference}

1. Syafei O, Eriksen M, Ross H, Mackay J. The Tobbacco Atlas- 3rd Edition. USA; 2009.

2. Islami F, Stoklosa M, Drope J, Jemal A. Global and Regional Patterns of Tobacco Smoking and Tobacco Control Policies. Eur Urol Focus. 2015;1(9):3-16.

3. The Tobacco Atlas Indonesia. Indonesia Fact Sheet [Internet]. Jakarta; 2015. Available from: https://tobaccoatlas.org/country/indonesia/

4. Badan Penelitian dan Pengembangan Kesehatan Kementerian Kesehatan Republik Indonesia. Riset Kesehatan Dasar (Riskesdas) dalam angka Provinsi Sumatera Selatan. Jakarta; 2013.

5. Badan Pusat Statistik Provinsi Sumatera Selatan. Jumlah Penduduk menurut Kabupaten/Kota di Provinsi Sumatera Selatan. Palembang; 2013.

6. Dinas Kesehatan Kota Palembang. Sepuluh Perilaku Remaja di Kota Palembang. Palembang; 2016.

7. Wahyuni D, Sudaryanto. Faktor - faktor yang berhubungan dengan sikap merokok pada remaja di desa karang tengah kecamatan sragen. 2010;120-9. 
8. Dharmawan Salim A. IMC: Promosi, Iklan dan Sponsor Rokok Strategi Perusahaan Menggiring Remaja untuk Merokok. BENEFIT J Manaj dan Bisnis. 2013;17(1):58-65.

9. Tobacco Control Support Centre - Ikatan Ahli Kesehatan Masyarakat Indonesia. Paparan Iklan, Promosi, dan Sponsor Rokok di Indonesia. Jakarta; 2018.

10. Whittaker R, Dorey E, Bramley D, Bullen C, Denny S, Elley CR, et al. A theory-based video messaging mobile phone intervention for smoking cessation: Randomized controlled trial. J Med Internet Res. 2011;13(1):1-12.

11. Nuradita E, Mariyam. Pengaruh pendidikan kesehatan terhadap pengetahuan tentang bahaya rokok pada remaja di SMP Negeri 3 Kendal. J Keperawatan Anak. 2013;1(1):44-8.

12. Ahmadi. Tentang Sikap yang Tercermin dari Perilaku. Jakarta: Rineka Copta; 2003.

13. Yusuf. Psikologi Perkembangan Anak dan Remaja. Bandung: Remaja Rosdakarya; 2012.

14. Aryal UR, Bhatta DN. Perceived benefits and health risks of cigarette smoking among young adults: Insights from a cross-sectional study. Tob Induc Dis. 2015;13(1):1-8.

15. Okoli CTC, Pederson A, Rice W. Support for a Smoke-free by Law in Parks and on Beaches. Health Policy (New York). 2013;111(2):127-34.

16. Virga RL. Literasi Iklan Rokok Dan Perilaku Konsumtif Remaja Melalui Pemberdayaan Remaja Masjid. Profetik J Komun. 2017;9(2):33-44.

17. Suratman dan Kuswanto. Gambaran Pemahaman Mahasiswa Terhadap Kebiasaan Merokok Serta Bahayanya Bagi Kesehatan Masyarakat Dan Kesehatan Lingkungan. J Ilm Kesehat Masy. 2004;4(1):11-24.

18. Aura A, Laatikainen T, Isoaho H, Lazutkina G, Tossavainen K. Adolescents' Attitudes on Smoking Are Related to Experimentation with Smoking, Daily Smoking and Best Friends' Smoking in Two Karelias in Finland and in Russia. Int J Behav Med. 2016;23(6):679-85.

19. Permatasari LY. Pengaruh Tanggung Jawab Sosial terhadap Citra Perusahaan PT Djarum (Studi Kasus Djarum Beasiswa Plus pada Mahasiswa Jember). Universitas Jember; 2016.

20. Noar SM, Francis DB, Bridges C, Sontag JM, Ribisl KM, Brewer NT. The Impact of Strengthening Cigarette Pack Warnings: Systematic Review of Longitudinal Observational Studies. Soc Sci Med. 2016;164(1):118-129.

21. Karibasappa G, Nagesh L, Usha G, Prakash S. Assessment of Awareness about Pictorial Warnings on Tobacco Products Among 15 Years and Above Age in Davangere City, Karnataka, India - A Cross Sectional Survey. Indian J Stomatol. 2011;2(4):227-32.

22. Hiilamo H, Crosbie E, Glantz SA. The evolution of health warning labels on cigarette packs: the role of precedents, and tobacco industry strategies to block diffusion. Tob Control. 2014;23(1):E2.

23. Simons-Morton B, McLeroy KR, Wendel ML. Behavior Theory in Health Promotion Practice and Research. 1st Editio. John and Barlett Learning; 2012. 
24. Etrawati F. Perilaku Merokok Pada Remaja : Kajian Faktor Sosio Psikologis. Ilmu Kesehat Masy. 2014;5(2):77-85.

25. Lee S, Cappella JN. Distraction Effects of Smoking Cues in Antismoking Messages: Examining Resource Allocation to Message Processing as a Function of Smoking Cues and Argument Strength. Media Psychol. 2013;16(2):154-176. 